\title{
Determination of Soil Erosion Vulnerability in the Lafa Basin of Ghana using RUSLE and GIS
}

\author{
Dr. Saviour Mantey ${ }^{1}$, Dr. Michael S. Aduah ${ }^{2}$ \\ ${ }^{1,2}$ Geomatic Engineering Department \\ University of Mines and Technology \\ Tarkwa, Ghana
}

\begin{abstract}
Soil erosion is the wearing away of the land surface by physical forces such as rainfall, flowing water, wind, temperature change, gravity, or other natural or anthropogenic agents. Soil erosion is one of the key variables used to assess and appreciate land degradation. The increased soil erosion in some portions of Lafa basin of Ghana has led to siltation of the river channel that is causing flooding in some parts of Accra, Ghana. Lafa basin is the most urbanised basin in Ghana. The objective of this study is to use Revised Universal Soil Loss Equation (RULSE) model and Geographical Information System (GIS) tool to determine the potential and actual soil erosion in the Lafa basin. Rainfall erosivity (R), slope length-steepness (LS), soil erodibility (K), cover management (C) and conversation practice (P) were used to generate soil erosion map and also Normalised Difference Vegetation Difference (NDVI) map from Landsat 7 image was generated to help produce cover management factor map. The model predicted $130 \mathrm{t} / \mathrm{ha} / \mathrm{yr}$ and $51 \mathrm{t} / \mathrm{ha} / \mathrm{yr}$ for potential and actual soil erosion of the study area, respectively. According to the model, most parts of the study area was not at risk to soil erosion although a few portions show very severe to highly severe soil erosion risks. The method developed can utilise existing data and provide results that are useful to managers when taking decisions about the management of land resources in the basin.
\end{abstract}

Keywords- RUSLE, Soil Erodibility, GIS, Lafa basin, Soil Erosion

\section{INTRODUCTION}

Soil erosion is the removal of surface material by rainfall, wind, flowing water, temperature, gravity or other natural or anthropogenic agents, each contributing a significant amount of soil erosion each year [1]. Soil erosion is a naturally occurring process [1]. Water is the more effective agent of soil erosion in humid climates [2]. Soil erosion may be a slow process that continues relatively unnoticed, or it may occur at an alarming rate causing serious loss of topsoil [2]. Soil erosion is a sequel of unsustainable land use [3] and other disturbances, such as, mining, fire or intensive agricultural uses [4]. The loss of soil may have critical impacts on the quantity and quality of soil ecosystem services, with severe economic, social and political implications [5],[6]. Soil compaction, low organic matter, loss of soil structure, poor internal drainage, salinisation and soil acidity problems are other serious soil degradation conditions that can accelerate the soil erosion process [7]. Soil takes a long time to build up and without it many plants cannot survive [7]. The loss of soil from farmland may be reflected in reduced crop production potential, lower surface water quality and damaged drainage networks [8]. There are different types of soil erosion, namely, sheet, rill, gully, bank, and wind erosions [9]. Sheet erosion occurs fairly evenly over an area. As raindrops loosen the soil, the surface water runoff can transport topsoil in a uniform fashion, almost like a "bed sheet" sliding off a bed. Rill erosion results in small, shortlived and well-defined streams. When rainfall does not soak into the soil, it can gather on the surface and run downhill, forming small channels of water called rills [9]. Gully erosion can be thought of as advanced rill erosion and if rills are not addressed, they will become larger gullies [10],[11]. Bank erosion is another type of water erosion and is defined as erosion of the bank of a stream or waterway [12]. Wind erosion is simply the loss of topsoil due to wind. Wind has more of a chance of eroding soil if the area does not have a lot of vegetation, which tends to lock the soil in place [13]

Accra consist of eight (8) drainage basins which include; Kpeshie, Korle, Densu, Sakumo, Lafa, Osu, Songo Mokwe and Chemu basins [14]. The Lafa basin in Accra has experienced some soil erosion which has negatively affected crop production and degraded the land in the catchment. Due to the negative effect of soil erosion, it has become necessary to determine the potential and actual soil erosion prone areas in the basin.

Revised Universal Soil Loss Equation (RUSLE) is a widely used mathematical model that describes soil erosion processes [15],[16],[17]. Erosion models play critical roles in soil and water resource conservation and nonpoint source pollution assessments, including: sediment load assessment and inventory, conservation planning and design for sediment control and for the advancement of scientific understanding. The RUSLE or one of its derivatives is the main model used by United States government agencies to measure water erosion [16],[18]. The advancement of GIS techniques has also made it possible to produce more accurate maps, often combining different data sources [19]. In recent years GIS has been used to estimate soil erosion and deposition areas worldwide [20],[21],[22], but using distributed GIS to model erosion is very rare in Ghana [23]. This paper therefore seeks to determine the potential and actual soil erosion in the Lafa basin using the Revised Universal Soil Loss Equation (RUSLE) and GIS tools.

\section{MATERIALS AND METHODS}

Study Area: Lafa basin is located about $9 \mathrm{~km}$ to the West of Accra and lies within three administrative jurisdictions of the Greater Accra Region. The basin lies between longitudes $0^{\circ} 18^{\prime} 33^{\prime \prime} \mathrm{W}$ and $0^{\circ} 15^{\prime} 26^{\prime \prime} \mathrm{W}$ and latitudes $5^{\circ} 34^{\prime} 12^{\prime \prime} \mathrm{N}$ and $5^{\circ} 38^{\prime} 22^{\prime \prime} \mathrm{N}$ and covers an 
approximate area of $28 \mathrm{~km}^{2}$. The basin has evolved from periurban into a completely urbanised status due to its proximity to central Accra, as it offers a preferred dwelling place for people who work in the capital city. The following towns are fast developing within the basin; Nsunfa, Anyaa, Palastown, Sowutuom, Israel, Race course, Santa Maria, Kwashieman, Mallam, Awoshie and Tabora. There is pressure on available space, thus encroaching on the floodplains and stream courses. Such situation causes floods even in short duration high intensity rainstorms. There are numerous socioeconomic infrastructure in the basin including schools, markets and a power sub-station.

Lafa basin lies in the savannah zone. There are two rainy seasons. The average annual rainfall is about $730 \mathrm{~mm}$, which falls primarily during the two rainy seasons [24]. The first begins in May and ends in mid-July. The second season begins in mid-August and ends in October. Rain usually falls in intensive short storms and gives rise to local flooding where drainage channels are obstructed [24]

There is very little variation in temperature throughout the year. The mean monthly temperature ranges from $24.7^{\circ} \mathrm{C}$ in August (the coolest) to $28{ }^{\circ} \mathrm{C}$ in March (the hottest) with annual average of $26.8{ }^{\circ} \mathrm{C}$. Relative humidity is generally high varying from $65 \%$ in the mid-afternoon to $95 \%$ at night. The predominant wind direction in the Lafa basin is from the WSW to NNE sectors. Wind speeds normally range between 8 to $16 \mathrm{~km} / \mathrm{hr}$. High wind gusts occur with thunderstorm activity, which pass in squall along the coast [24].

The maximum wind speed record in Lafa is $107.4 \mathrm{~km} / \mathrm{hr}$. (58 knots) [24]. Strong winds associated with thunderstorm activity often cause damage to property by removing roofing materials. Several areas in Accra experience micro climatic effects. Low profile drainage basins with a North-South orientation are not as well ventilated as that orientated EastWest. Air is often trapped in pockets and an insulation effect gives rise to local increase in air temperature of several degrees.

Materials and Methods: The materials used in this study as inputs to generate parameters for the RUSLE formula in Equation (1) include; Annual rainfall data, Soil map, DEM of the Lafa basin and Land use map. The input data for the conceptual model include; soil, rainfall, and digital elevation model (DEM) and its derivative slope map. The following maps were generated from the input data: Topographic Factor (LS), Conservation Practice Factor (P), Rainfall and Runoff Erosivity Factor (R), Soil Erodability Factor (K) and Cover and Management Factor (C).

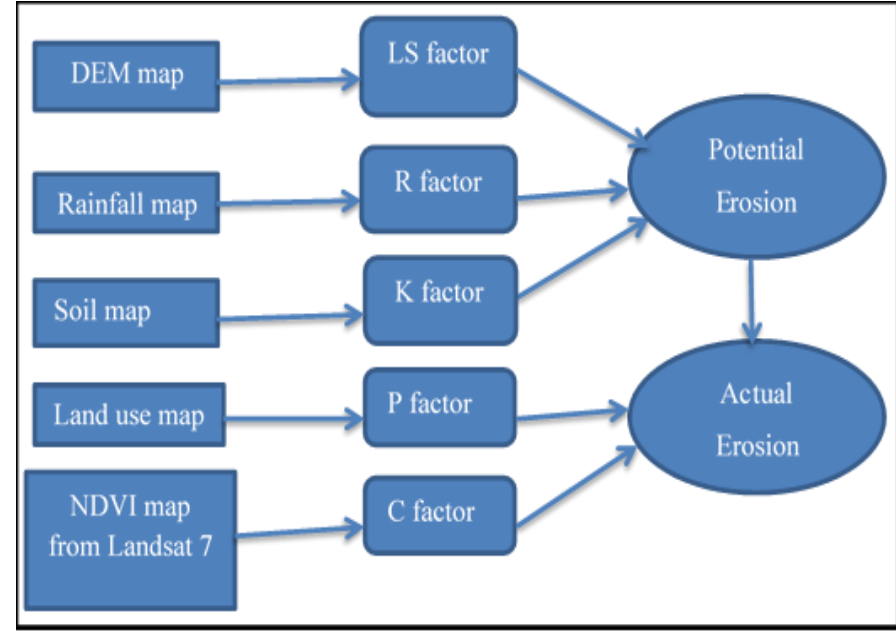

Fig. 1 A Flow Chart showing Methods Used

\section{Estimation of Soil Erosion using RUSLE}

The Revised Universal Soil Loss Equation (RUSLE) is given by Equation (1)

\section{$\mathrm{A}=\mathrm{R} * \mathrm{~K} * \mathrm{LS} * \mathrm{C} * \mathrm{P}$}

Where; $\mathrm{A}$ is average annual soil loss in t/a (tons per acre); $\mathrm{R}$ is rainfall erosivity index; $\mathrm{K}$ is soil erodibility factor; $\mathrm{LS}$ is topographic factor ( $\mathrm{L}$ is for slope length $\& \mathrm{~S}$ is for slope); C is crop management factor and $\mathrm{P}$ is conservation practice factor.

\section{Estimation of Topographic Factor (LS)}

The topographic factor (LS) was estimated in four steps using the digital elevation model (DEM) of the Lafa basin.

Flow Direction map was calculated using flow direction tool, while

Flow Accumulation was calculated with flow accumulation tool, using the flow direction map as input.

Slope was calculated in degrees with slope tool using the DEM as input layer.

LS factor was finally calculated using the Equation (2):

$$
\begin{aligned}
& \text { LS }=\text { Pow }\left([\text { flow accumulation }] * \frac{\text { resolution }}{22: 1_{1} 0.4}\right) * \\
& \text { Pow } \sin \left(\frac{[\text { slope of } D E M]}{0.09,1,4}\right) * 1.4
\end{aligned}
$$

where Pow (which means power) is a function in the ArcGIS spatial Analyst.

\section{Estimation of Conservation Practice Factor $(P)$}

The $\mathrm{P}$ factor is a management soil erosion control. It helps protect the top soil from erosion. It is intentional initiatives of the farmers to control soil erosion. The $\mathrm{P}$ factor can range from 0.01 in case there is almost maximum cover to 1 , where there is no cover. The application of contour ploughing, for instance, can reduce $\mathrm{P}$ factor value to 0.1 . In GIS, the $\mathrm{P}$ factor was generated as follows:

Land use data was used to generate a land use map.

Slope map was created in degrees with slope tool.

Classification was done using reclassify tool.

The map was then converted from raster to polygon. 
The support practice factor is calculated based on the relation between terracing and slope in the Lafa basin.

The map was then converted back to raster. The $\mathrm{P}$ factor map was then generated.

\section{Estimation of Rainfall Factor (R)}

The power of rainfall to erode a soil is called erosivity (R) and it depends on rainfall intensity and amount. High rainfall intensity will easily splash or remove top soil, and it can also cause mass movement. In GIS, $\mathrm{R}$ factor was generated with the equation, $\mathrm{R}=38.5+0.35^{*} \mathrm{P}$, Where $\mathrm{P}$ is the $\mathrm{P}$ factor map. In this case the $\mathrm{P}$ factor map was already generated. The $\mathrm{R}$ factor was then created using the raster calculator in the ArcGIS software.

\section{Estimation of Soil Erodibility Factor (K)}

Soil erodibility depends on soil and, or geological characteristics, such as parent material, texture, structure, organic matter content, porosity, catena and many more [25]. For less erodible soil, K value of $0.1 \pm 0.05$ is acceptable and in GIS it can be considered a lumped parameter such as $\mathrm{K}=$ 0.1 [26]. Or it can be estimated based on soil or geological groups. West African soil groups used to produce erodibility (K) map are presented in Table 1 .

Table 1: K Values for Soil with Different Textures ([27])

\begin{tabular}{|l|c|}
\hline Soil Group & Erodibility (K) \\
\hline Sandy, fine sand, loamy sand & 0.1 \\
\hline $\begin{array}{l}\text { Loamy sand, loamy fine sand, sandy loam loamy, } \\
\text { silty loam }\end{array}$ & 0.15 \\
\hline Loamy, silty loam, sandy clay loam, fine sandy loam & 0.24 \\
\hline Silty clay loam, silty clay, clay loam, clay & 0.28 \\
\hline
\end{tabular}

\section{Estimation of Crop Management Factor $(C)$}

In order to determine the erosion caused by land cover, the approach used to calculate the coefficient $\mathrm{C}$ was based on
Normalised Difference Vegetation Index (NDVI) which was derived from the Landsat 7 images. NDVI was calculated using Equation (3) [28], [29].

$$
\mathrm{NDVI}=(\mathrm{NIR}-\mathrm{Red}) /(\mathrm{NIR}+\mathrm{Red}) .
$$

Where NIR and Red are the near-infrared and red bands of the Landsat 7 images of the Lafa basin area. For Landsat 7, the near-infrared (NIR) band corresponds to band 4, and the red band (Red) corresponds to band 3. Raster Calculator in the ArcGIS software was used to calculate both the NDVI and the $\mathrm{C}$ factor. In this study, the formula to calculate the coefficient of erosion by $\mathrm{C}$ factor is provided in Equation (4).

$\mathrm{C}$ factor $=0.432-0,025 * \mathrm{NDVI}$

\section{RESULTS AND DISCUSSION}

Results: The maps for R, K, LS, P and C factor of RUSLE model were developed using GIS tools. Figures 2 and 3 show the topographic factor (LS) and soil erodibility factor $(\mathrm{K})$, which were generated using DEM map and soil map respectively of the Lafa basin.

Also, Figures 4 and 5 shows the maps of conservation practice factor $(\mathrm{P})$ and runoff erosivity factor $(\mathrm{R})$, using land use map and annual rainfall data respectively. Figure 6 also shows the map of cover and management factor (C) generated using NDVI map of Landsat 7 images.

Potential soil loss is the process of erosion when the impact of the conservation practice factors and cover and management factors have not been considered. Therefore, the potential soil loss map (Figure 7) was determined by integrating the map coefficients; $\mathrm{R}, \mathrm{K}$ and $\mathrm{LS}$, while the actual soil loss map was determined using $\mathrm{R}, \mathrm{K}, \mathrm{LS}, \mathrm{P}$ and $\mathrm{C}$ map coefficients as presented in Figure 8. 


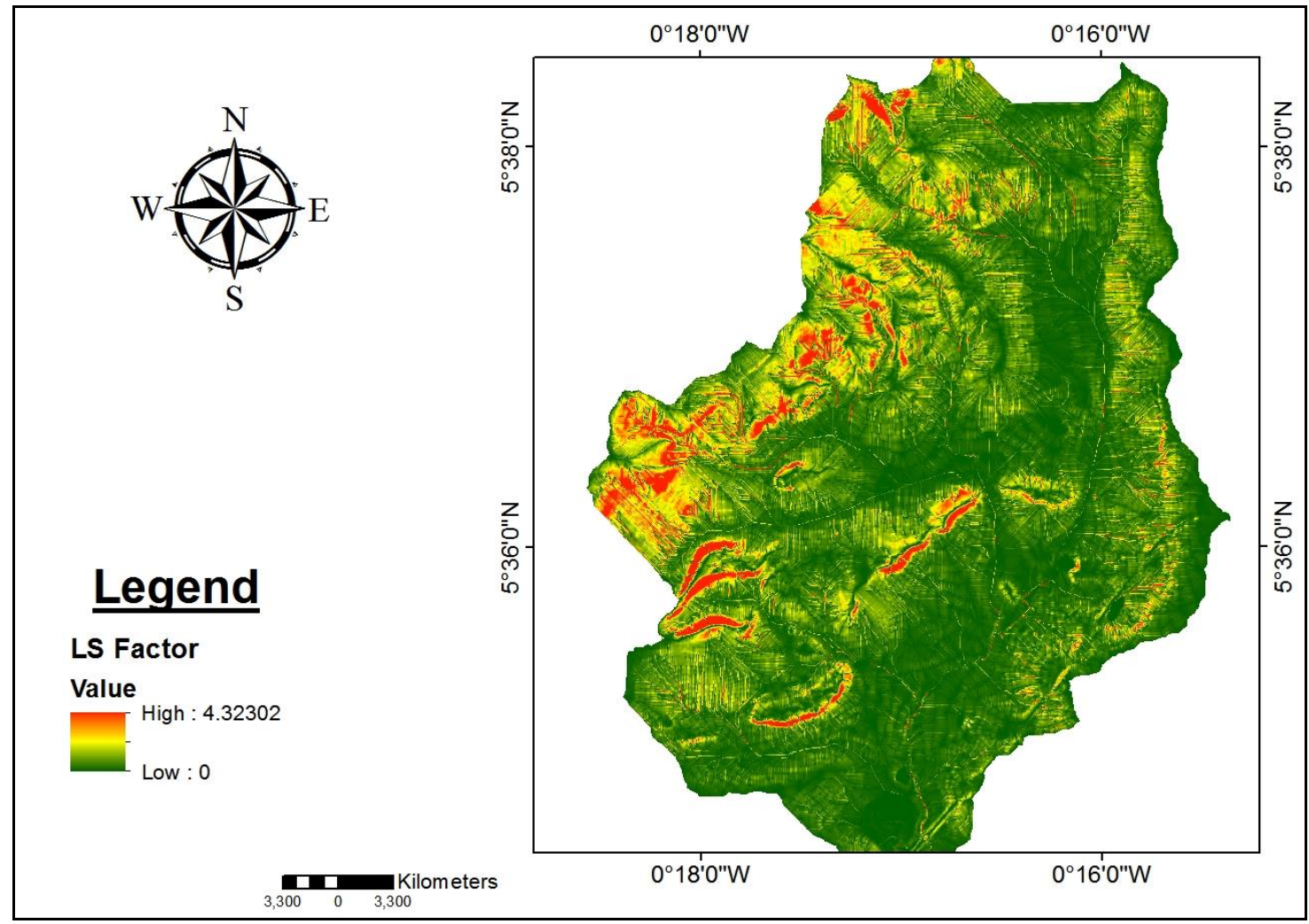

Fig. 2 LS Factor

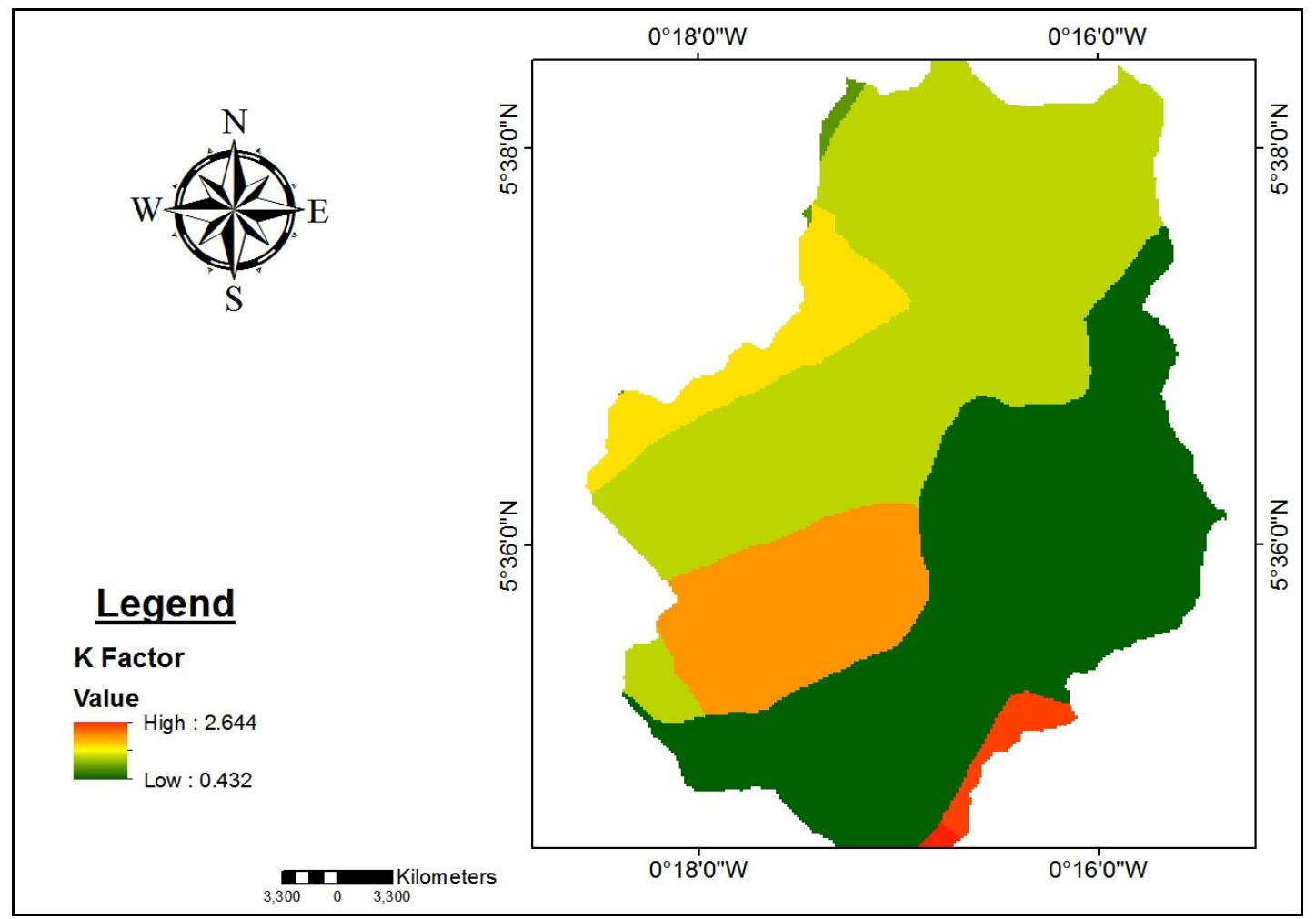

Fig. 3 K Factor 


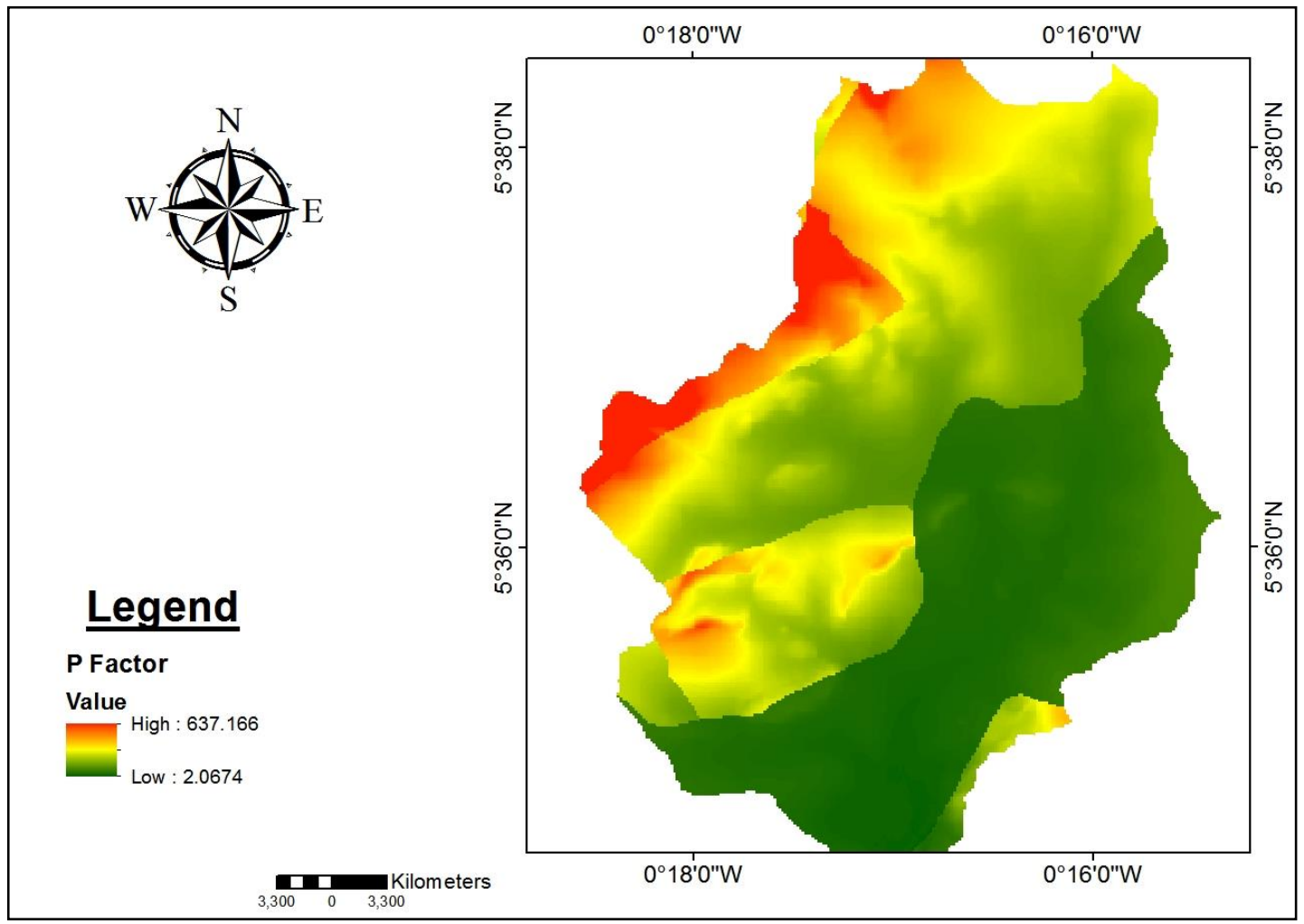

Fig. 4 P Factor

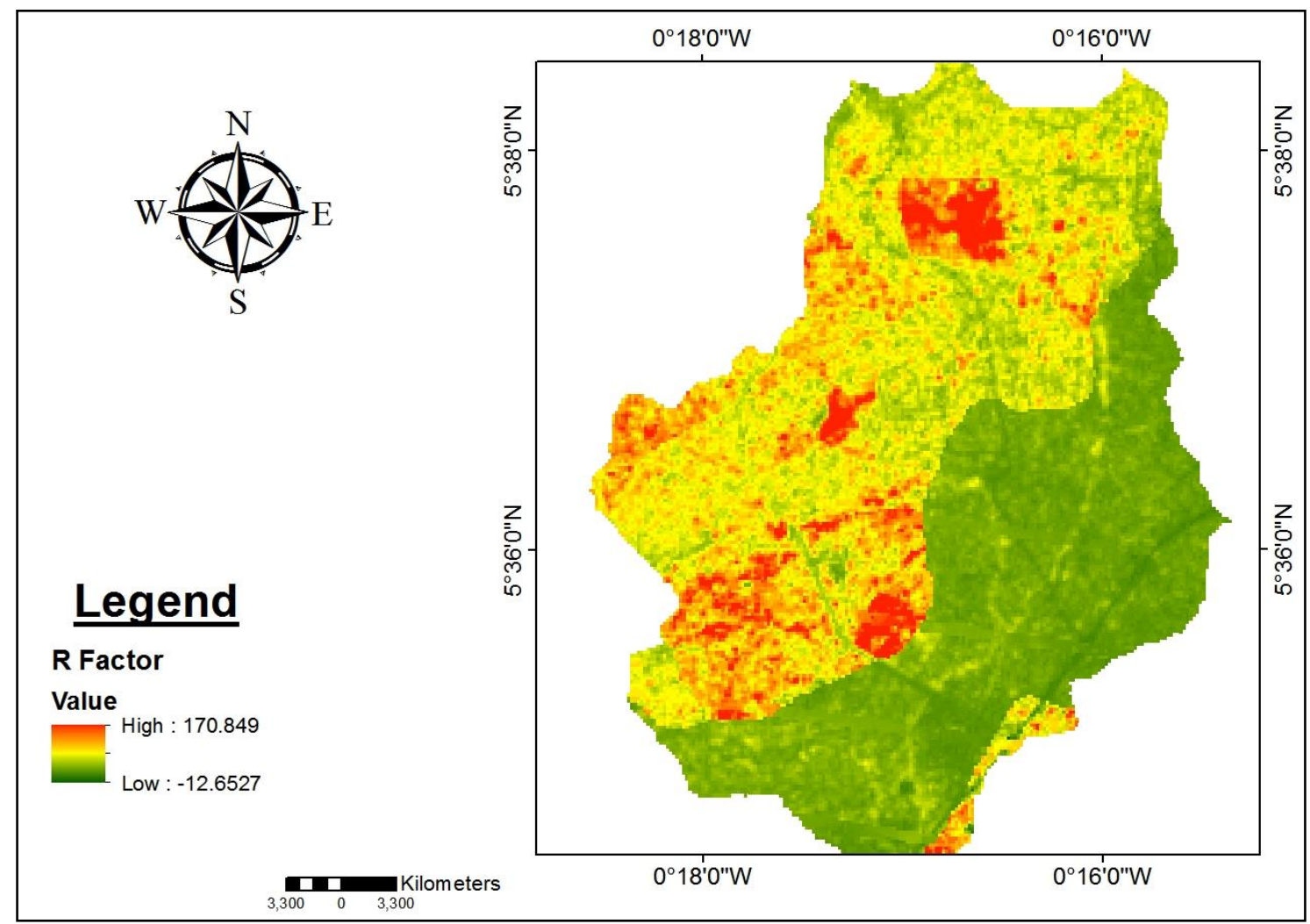

Fig. 5 R Factor 


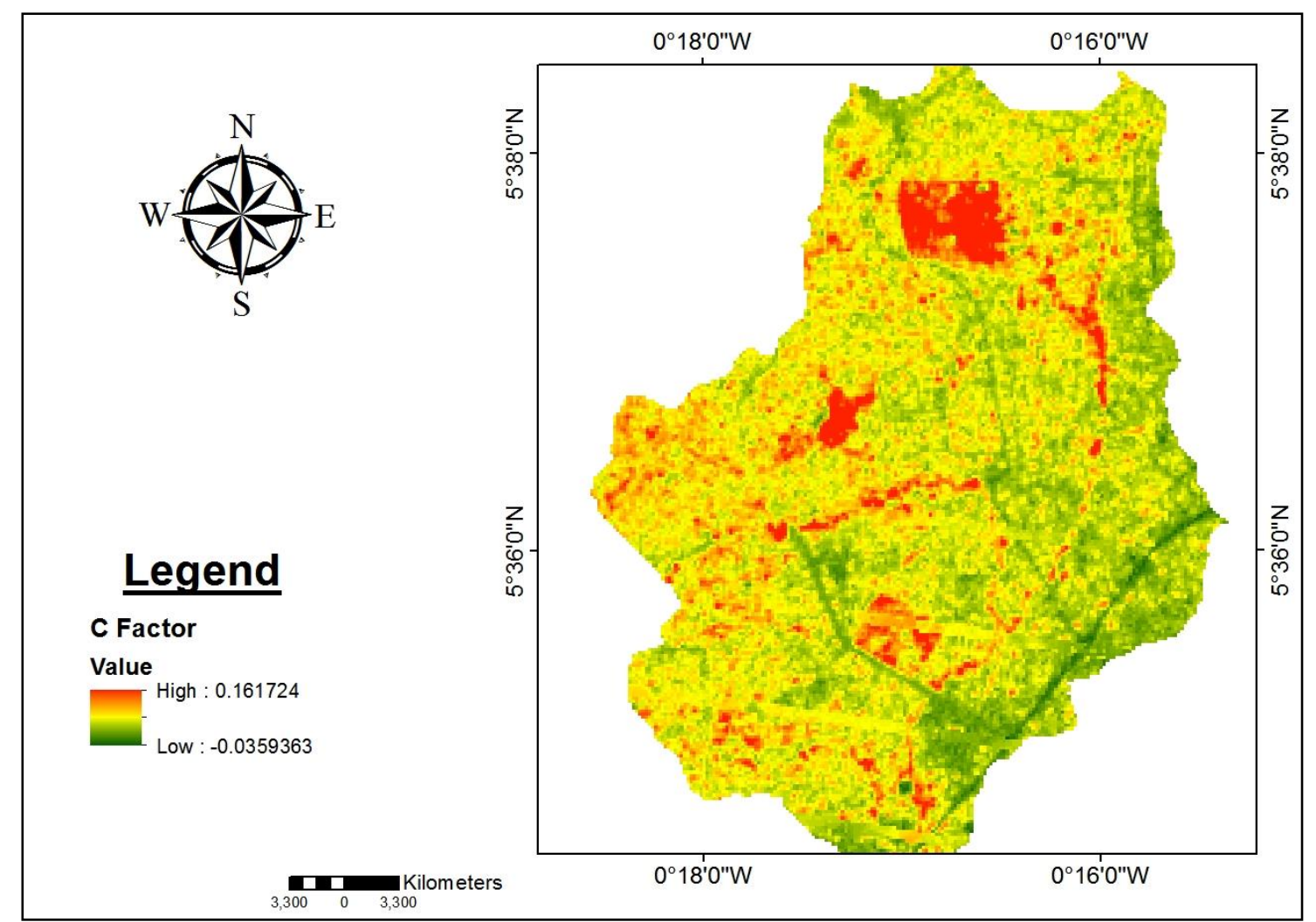

Fig. 6 C Factor

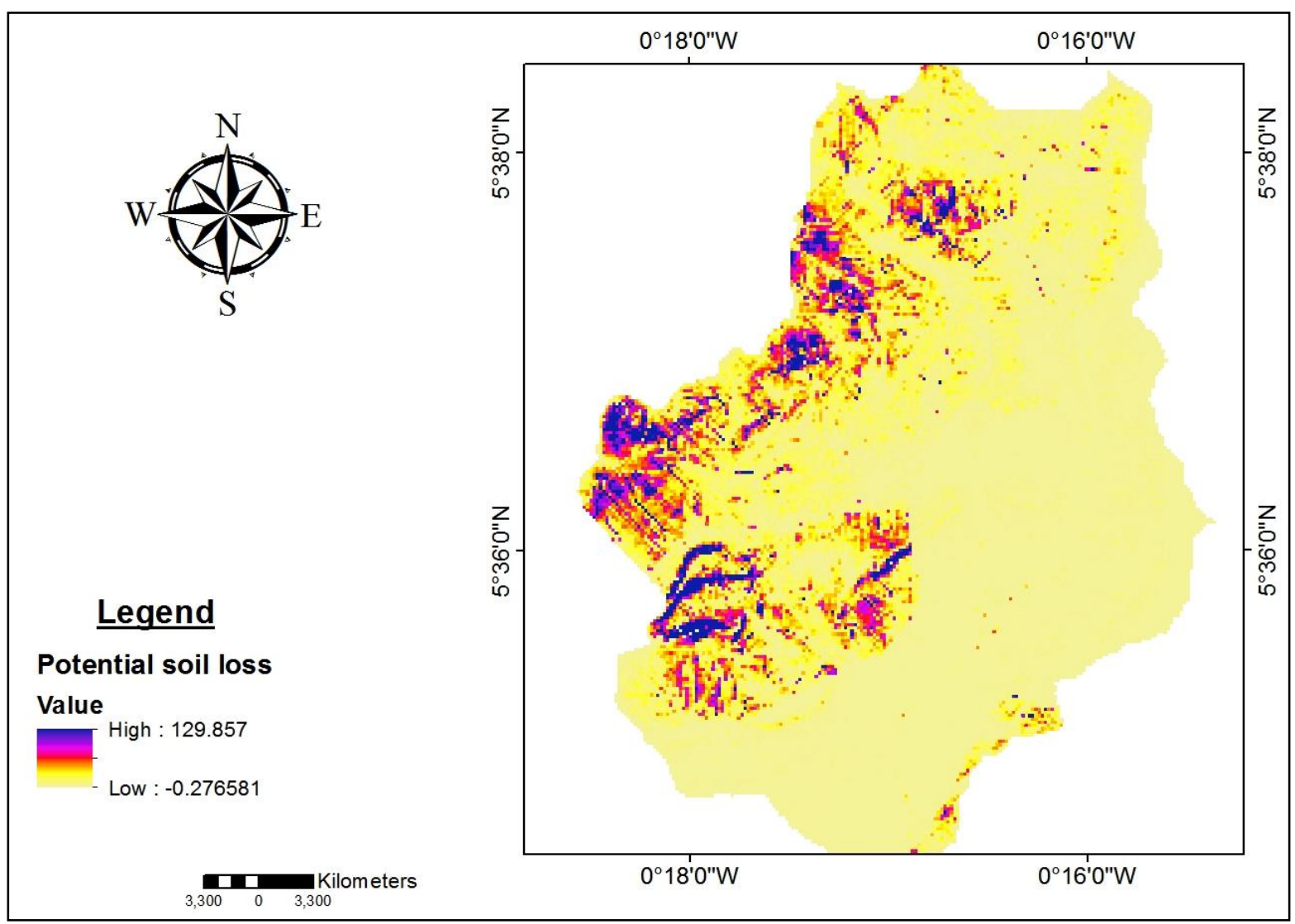

Fig. 7 Potential Soil Loss 


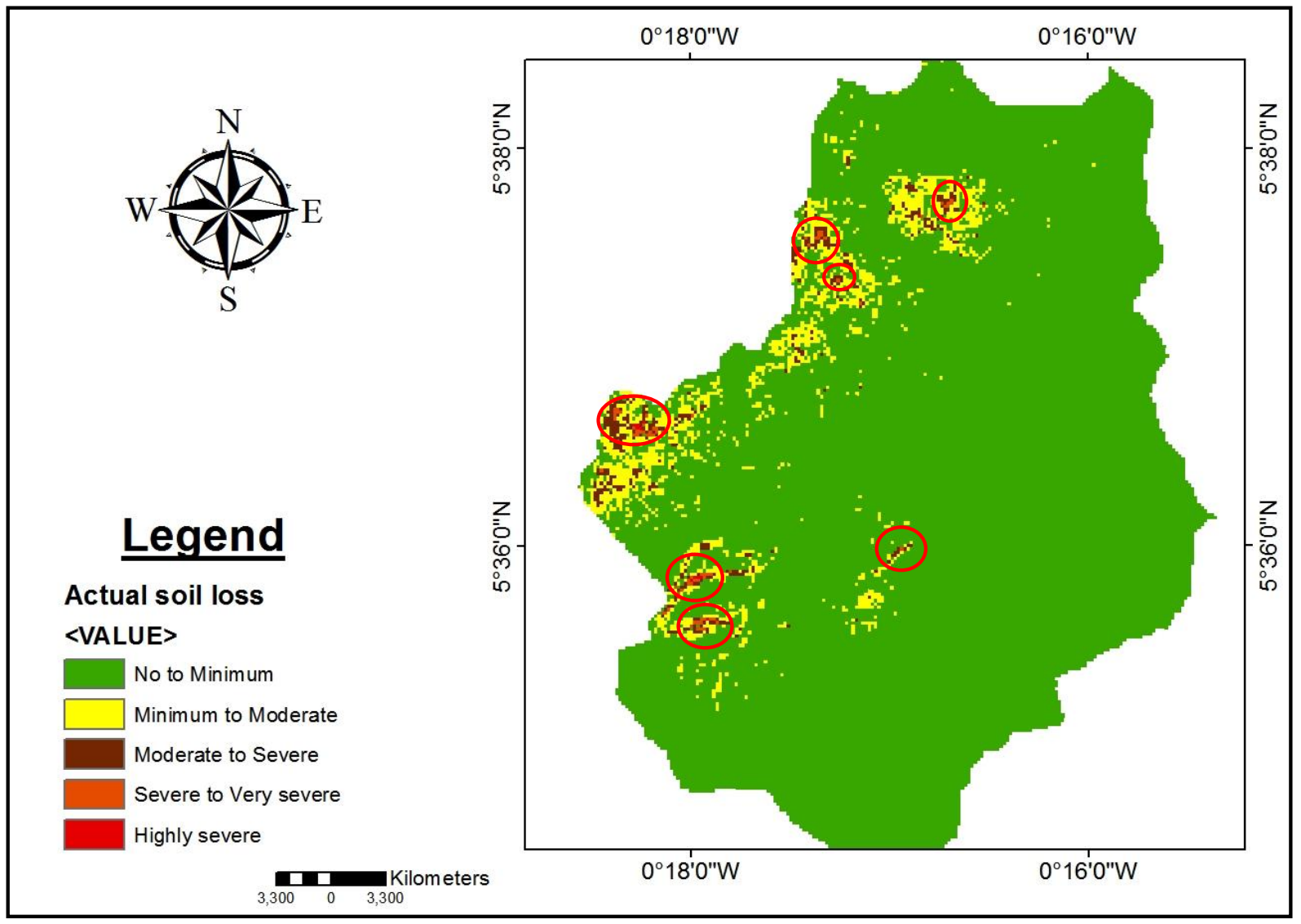

Fig. 8 Actual Soil Loss

Discussion: In determining the potential soil loss, the LS, K and $\mathrm{R}$ factors were used excluding $\mathrm{P}$ and $\mathrm{C}$ factors. During this calculation, the land is assumed to be bare without any land cover and proper conservation practice to protect it from direct surface runoff. Figure 7 indicates that the maximum potential soil loss of Lafa basin is $130 \mathrm{t} / \mathrm{ha} / \mathrm{yr}$. However, from Figure 8, it can be observed that the actual soil erosion in the study area has reduced from $130 \mathrm{t} / \mathrm{ha} / \mathrm{yr}$. to $51 \mathrm{t} / \mathrm{ha} / \mathrm{yr}$ after including the vegetation cover $(\mathrm{C})$ and conservation practice $(\mathrm{P})$ factors. This indicate that vegetation cover and proper conservation practices have the potential to substantially reduce soil erosion.

\section{CONCLUSIONS AND RECOMMENDATION}

Conclusions: In conclusion, most parts of the study area such as Race course, Mallam, Awoshie, Santa Maria and Tabora showed relatively low erosion risk. Other areas in the basin such as Nsunfa, Anyaa, Sowutuom and Palastown were exposed to severe to very severe and highly severe erosion risks. From this study, RUSLE and GIS tools have proven to be effective for soil erosion modeling and erosion risk assessment. This study also confirms that a good conservation practice and vegetative cover could reduce the risk of actual soil erosion. Detecting areas affected by soil erosion is important to develop and assess areas that need to be restored and to promote awareness among decision makers.
Recommendation: Comparing and analysing the potential soil loss and the actual soil loss maps, the cause of increased soil erosion was lack of land cover such as vegetation and proper land use management. It is therefore recommended that increasing vegetation cover at the erosion affected areas can reduce surface runoff and protect surface pores and also inculcate good conservation practices.

\section{REFERENCES}

[1] Ramos M. C. and Martínez-Casasnovas J. A. (2006), "Erosion rates and nutrient losses affected by composted cattle manure application in vineyard soils of NE Spain", CETENA, Elsevier, Vol. 68, Issues 2-3, pp. $177-185$

[2] William, J. (1995), "Channel and habitat change downstream of urbanization. In Herricks, Edwin E. \& Jenkins, Jackie R. Storm water Runoff and Receiving Systems: Impact, Monitoring, and Assessment", CRC Press, Taylor and Francis Group, pp. 105.

[3] Cerdà A., Lavee, H., Romero-Diaz, A., Hooke, J., and Montanarella, L. (2010), "Soil erosion and degradation in Mediterranean type ecosystems", Land Degradation and Development, Vol. 21, pp. 7174.

[4] Cerdà, A. and Doerr, S.H. (2008), "The effect of ash and needle cover on surface runoff and erosion in the immediate post-fire period", Catena, Vol. 74, pp. 256- 263.

[5] De Vente, J., Poesen, J., Verstraeten, G., Govers, G., Vanmaercke, M., Van Rompaey, A., Arabkehdri, M. and Boix-Fayos, C., (2013), "Predicting soil erosion and sediment yield at regional scales: where do we stand?" Earth-Science Reviews, Vol. 127, pp. 16-29.

[6] Panagos, P., Borrelli, P., Poesen, J., Meusburger, K., Ballabio, C., Lugato, E., Montanarella, L. and Alewell, C. (2016), "Reply to The new assessment of soil loss by water erosion in Europe", Environmental Science and Policy, 54, 438-447-A response" by 
Evans and Boardman [Environmental Science \& Policy 58, 11-15], Environmental Science \& Policy, Vol. 59, pp. 53-57.

[7] Blanco, Humberto and Lal Rattan (2010). "Soil and water conservation. Principles of Soil Conservation and Management", Springer, pp. 1-20.

[8] Toy, Terrence J. (2002). Soil Erosion: Processes, Prediction, Measurement, and Control. John Wiley and Sons. pp. 1.

[9] Nearing, M.A., Norton, L.D., Bulgakov, D.A., Larionov, G.A. West, L.T. and Dontsova, K.M. (1997). "Hydraulics and erosion in eroding rills", Water Resources Research, Vol. 33, No. 4, pp. 865876.

[10] Poesen, Jean, (2007). "Gully erosion in Europe". In Boardman, John \& Poesen, Jean. Soil Erosion in Europe. John Wiley \& Sons, pp. 516-519.

[11] Poesen, J. (2018), "Soil erosion in the Anthropocene: research needs", Earth Surface Processes and Landforms, Vol. 43, No. 1, pp. 64-84.

[12] Borah, Deva K. (2008). "Watershed sediment yield. In Garcia, Marcelo H. Sedimentation Engineering: Processes, Measurements, Modeling, and Practice", American Society of Civil Engineers Publishing, pp. 828.

[13] Zachar, D. (1982). "Classification of soil erosion", Soil Erosion, Vol. 10, Elsevier, ISBN 978-0-444- 99725-8. 48pp.

[14] Anon, (2008), "SWITCH Accra City Story Stormwater Solutions in Ghan", Available at: https://www.waterworld.com/international/article/16202127/stormw ater-solutions-in-ghana, [Accessed: $31^{\text {st }}$ December, 2019]

[15] Lane, L. J., Shirley, E.D., and Singh, V. P., (1988), "Modelling Erosion on Hillslopes. In: Modelling Geomorphological Systems", John Wiley and Sons, Chichester, (editored by M.G. Anderson), pp. 287-308.

[16] Wischmeier, W. H., and D. D. Smith, (1978), "A universal soil-loss equation to guide conservation farm planning", $7^{\text {th }}$ Transactions of International Congress of Soil Science, pp. 418-425.

[17] Beskow S., Mello C. R., Norton L. D., Curi N., Viola M. R. and Avanzi J. C. (2009), "Soil erosion prediction in the Grande River Basin, Brazil using distributed modeling", Catena, Vol. 79. pp. 4959.

[18] Hudson, Norman (1993), "Field Measurement of Soil Erosion and Runoff", Issue 68. Food and Agriculture Organization of the United Nations. pp. 121-126.

[19] Fernandez P., Mourato S. and Moreira M. (2016), "Social vulnerability assessment of flood risk using GIS-based multicriteria decision analysis. A case study of Vila Nova de Gaia (Portugal)", Geomatics, Natural Hazards and Risk, Vol. 7, pp.1367-1389.

[20] Jha, M. K. and Paudel, R. C. (2010), "Erosion Predictions by Empirical Models in a Mountainous Watershed in Nepal", Journal of spatial hydrology, Vol. 10, No. 1, pp. 89-102.

[21] Mitasova, H., J. Hoerka, M. Zlocha, and R. L. Iverson, (1996), "Modeling topographic potential for erosion and deposition using GIS", International Journal of Geographical Information Systems, Vol. 10, No. 5, pp. 629-641.

[22] Subramani T., Krishnan S. and Kumaresan P. K. (2012), "Study of Groundwater Quality with GIS Application for Coonoor Taluk in Nilgiri District", International Journal of Modern Engineering Research, Vol. 2. No. 3, pp. 586-588.

[23] Clarke, K. C., (1986), "Advances in geographic information systems", computers, environment and urban systems, Elsevier, Vol. 10, Issues 3-4, pp. 175-184.

[24] Anon. (2016), "Average Conditions Accra, Ghana". http://www.bbcweatherafrica.org.uk. [Accessed: February 16, 2016].

[25] Schwab G. O., Fangmeier D. D., Elliot W. J., and Frevert R. K. (1993), "Soil and water conservation engineering", Forth Edition, John Wiley and Sons, Inc, New York, 507pp.

[26] Burrough P. A., and McDonnell R. A. (1998), "Principles of Geographical Information Systems" Engineers, John Wiley and Sons, Inc. New York, 796pp.

[28] Jensen J. R. (2000), "Remote Sensing of the Environment: An Earth Resource Perspective, 2nd edition", Prentice-Hall, Inc. Upper Saddle River, NJ; pp. 544.

[29] Tucker C. J., Pinzon J. E, Brown M. E, Slayback D, Pak E. W, Mahoney R, Vermote E, and El Saleous N. (2005), "An Extended AVHRR 8-km NDVI Data Set Compatible with MODIS and SPOT Vegetation NDVI Data", International Journal of Remote Sensing, Vol. 26, No. 20, pp. 4485-5598. 